\title{
Equity Price Influencing Factors of Financial Sector Firms in Nigeria
}

\author{
Effulgence \\ Vol. 16 (Special Issue) \\ January - June, 2018 \\ Rukmini Devi Institute of Advanced Studies \\ E-mail: effulgence@rdias.ac.in, Website: www.rdias.ac.in \\ http://effulgence.rdias.ac.in/user/default.aspx \\ https://dx.doi.org/10.33601/effulgence.rdias/v16/iSpl1/2018/article0.6
}

\begin{abstract}
A bdullahi Ismaila O lotu, Department of A ccounting, Nasarawa State University, K effi-Nigeria, ismailaolotu@ nsuk.edu.ng M isa A damu G assol, Department of Finance and A ccounts, M ilitary Pension B oard, A buja-N igeria, gassoladamu@ yahoo.com A bdullahi M usa A bdullahi, Department of T axation, N asarawa State University, K effi-Nigeria, aamusa@ nsuk.edu.ng
\end{abstract}

\begin{abstract}
Arguments have abounded in what really influence the prices of equities. From the point of the efficient market hypothesis claim that only market fundamental factors are priced into stock to other lines of arguments that even microeconomic variables and psychological factors affects stock prices have continued to generate interest. F or a developing country like Nigeria, the effectiveness of some of the factors identified in literature are even less certain. This study specifically targeted listed firms in the financial sector of the Nigerian stock exchange to examine the influencing power of key accounting and macroeconomic variables on stock prices. 0 ut of the fifty eight (58) listed financial sector firms a sample of forty five (45) where purposefully selected based on the availability of monthly data for the period of year 2010 to 2015. The data were analysed using random effect based regression model based on the suggestion of Hausman test. The result of the analysis shows that all the variables, vis-à-vis earnings per share, price earnings ratio, market capitalization, oil price and exchange rate are significant determinants of stock price except for liquidity. Specifically, factors such as oil price and exchange rate all have negative influence on equity price. This implies that on a specific note, macroeconomic polies of the federal government is not in favor of the stock market. It is recommended that government must pursue a stable policy that will help stabilize the exchange rate. This will keep the performance of the market stable and in courage more stability of prices in the market.
\end{abstract}

Key words: Stock price, Accounting fundamentals, macroeconomic variables

\section{INTRODUCTION}

Stock market provides opportunities for firms to raise capital in order to finance their business activities. The market also provide opportunities for investor to gain on their investment by way of capital appreciation. The movement in share price thus is a point of concern to the investors, since an upward drift will result in capital appreciation for them. A lot of factors have been identified as the drivers of stock market prices. The factors identified in the literature include business environment provided by macroeconomic variables such as inflation and monetary policies (Srinivasan, 2012). The firm specific variables are priceearnings ratios, book-to-market ratio, dividend payout, and firm level volatility. M ost available studies on the determinants of stock price have used these variables taking into consideration only aggregate level data such as All Share Index (ASI) as a proxy for stock price in Nigeria. Thus, most of these studies do not take into consideration the sectorial stock price behaviour. Since there are large tendencies of heterogeneity in firm's characteristics, using lumped data will not bring out the peculiar factors that influence specific sector in the stock market. This study, therefore, rather than the usual practice of aggregate level test, focuses on sectorial analysis using panel data approach. The financial sector is the major sector in the Nigerian stock market, yet the key drivers of prices in the sector have not been empirically been well documented. Therefore, this study examine the stock price influencing factors in the sector.

A gain, the use of accounting related variables has not been adequately examined. In Nigeria, most of the available studies concentrated on macroeconomic variables (Udegbumnam \& Eriki, 2010 and Mbutor 2007). However, the primary determinants of stock price should be the market fundamentals which are transmitted through accounting data such as price earnings ratio and book to market ratio (Fama \& French, 1992). This study therefore bridged the gap by using both combination of macroeconomic variables and accounting variables using monthly data to see how they affects stock prices in the Nigerian stock market. 
The remaining part of this study addresses the literature review, the methodology of the study, results and discussion and finally, conclusion and recommendation.

\section{LITERATURE REVIEW}

The concept of stock price determination has continued to generate interest in the finance literature. From the random work model, efficient market hypothesis, capital asset pricing model to adaptive market hypothesis; different directions of discussion has continued to generate interest on what are key variables that influence stock price movement. Generally, literatures have identified key accounting variables and some macroeconomic variables as price influencing factors. In this section, the links between the selected variables and stock price movement are discussed.

A mongst the stock price influencing factors, dividend payment has received a considerable attention. K han, Aamir, Qayyum, Nasir, and K han (2011) studied the effect of dividend payment on stock prices of five listed firms in the $K$ arachi Stock Exchange. The results of the study shows that dividend yield, earnings per share, return on equity and profit after tax are positively related to stock prices while retention ratio has negative relation with stock prices. In the same line of study, Matthew, Innocent and A nyanwaokoro (2014) examined the effect of dividend payment on the market prices of shares in Nigeria. It was also found that dividend significantly affects stock price movement in Nigeria.

Studies like Y akubu, Elijah and Sampson (2013) and Frank, Evans and Newman (2016) focused on the influence of corporate earnings announcement on stock prices in Ghana. The first finds evidence that earnings influences stock price, on the other hand, the later finds otherwise. The differences is likely due to the choice of trading days and event widow which the study of Evans et.al (2016) has higher average.

Eita (2012) found macroenonomic variables to significantly move stock prices in Namibia. Henriques and Sadorsky (2008) using vector autoregression (VAR) model found macroeconomic variables like exchange rate, oil price and inflation as significant determinants of stock prices. Even A fshar et al (2008) found oil price and exchange rate as determinants of stock price variability.
Moreover, Rahman (2009) examined the interactions between selected macroeconomic variables and stock prices of Malaysia in a VAR framework using the monthly data from January 1986 to $M$ arch 2008. The results indicate that Malaysian stock market price index has a cointegrating relationship with changes in money supply, interest rate, exchange rate, reserves and industrial production index. A rouri and Rault (2010) examined the sensitivity of stock price to oil price of Corporation Countries (GCC) to determine what causes what. The study found that for Saudi A rabian market, there is a consistent bi-directional causality between the two variables, while for the other GCC countries there was a unidirectional causality from oil prices to stock prices.

In Nigeria, Chukwunonso (2014) examined the relationship between oil prices and stock prices in Nigerian. The data isanalysed using A utoregressive integrated moving average model. The results of the study documented no cointegration between stock prices and oil prices, the use of an ARIMA and a structural-ARIMA model showed that oil price is a significant exogenous variable which could improve the accuracy of stock price prediction in the Nigerian stock market by an extent.

Quadir (2012) investigated the effects of macroeconomic variables such as Treasury bills rate and industrial production on stock returns on Dhaka Stock Exchange for the period between January 2000 and February 2007. The study usedmonthly time series data by applying Autoregressive Integrated Moving Average (ARIMA) model. Though the results showed a positive relationship between the selected variables and stock price, the coefficients are statistically insignificant. This implies that the findings of this work does not contradicts the previous studies above.

Studies have also examinedthe reactivity of stock price to the level of capitalisation. Oluwatoyin and Gbadebo (2009) examined the link between stock market capitalisation and stock market performance. The study found market capitalisation to have significant effect on stock market price. The study is only on a single firm. Dimitrios, Dimitriosloannis and A thina (2011) examined how Inflation, Market Capitalization, Industrial Production and the economic sentiment indicator affect EU-12 stock market price using panel model. The data collected were analysed using regression analysis. The empirical results revealed a strong 
effect of the first three factors, while inflation has a negative but not statistically significant coefficient. Further, the variables that affect the stock markets positively are market capitalization and the economic sentiment indicator. Finally, an applied statistical model confirms the significant convergence of the EU-12 stock markets in the long run, indicating a low geographic diversification across European markets. Kamunde (2012) examined the effect of market capitalisation on stock market indices (stock price) in Kenya. The study employs time series analysis with the data analysed using regression analysis. The study established that there exists a strong positive relationship between market capitalization and the NSE indices.

\section{METHODOLOGY}

The population of this study comprised of all the listed financial sector firms in the Nigerian stock market. There are fifty eight (58) listed firms in the financial sectors of the Nigerian stock exchange as at $31^{\text {st }}$ December, 2015. The financial sector comprises of the banking sector, insurance sector, mortgage carriers, microfinance banks and other financial services firms. The period of the study starts from the year 2010 in order to do away with the case of outlier in the data as the result of the global financial crisis of year 2008. Out of the total of 58 firms, a total of 45 where selected based on

\section{Table 1 Descriptive Statistics of the Variables}

\begin{tabular}{|c|c|c|c|c|c|c|c|}
\hline & PR & EPS & EXR & $\mathrm{MC}$ & OP & PE & VLT \\
\hline Mean & 7.412641 & 1.447649 & 143.0471 & $1.06 \mathrm{E}+11$ & 90.20019 & 13.45331 & 8634608. \\
\hline Median & 1.500000 & 0.290000 & 145.7900 & $1.68 \mathrm{E}+10$ & 100.4500 & 7.285714 & 1681208. \\
\hline Maximum & 552.2000 & 221.5148 & 180.1500 & $8.81 \mathrm{E}+11$ & 117.7900 & 408.0000 & $2.88 \mathrm{E}+08$ \\
\hline Minimum & 0.500000 & 0.004400 & 103.1300 & $3.60 \mathrm{E}+08$ & 36.56000 & 0.165514 & 0.000000 \\
\hline Std. Dev. & 36.66146 & 11.28041 & 21.51001 & $1.78 \mathrm{E}+11$ & 21.37105 & 23.95624 & 18331531 \\
\hline Skewness & 14.29308 & 18.64457 & -0.155775 & 2.286023 & -1.016576 & 9.367727 & 5.675299 \\
\hline Kurtosis & 212.4027 & 361.2907 & 1.964383 & 7.799631 & 2.713864 & 125.7019 & 55.56207 \\
\hline J arque-Bera & 2994526 . & 8699507. & 78.40955 & 2945.816 & 282.6195 & 1032895. & 193858.2 \\
\hline Probability & 0.000000 & 0.000000 & 0.000000 & 0.000000 & 0.000000 & 0.000000 & 0.000000 \\
\hline $\begin{array}{l}\text { Sum } \\
\text { Sum Sq. }\end{array}$ & 11926.94 & 2329.267 & 230162.7 & $1.71 \mathrm{E}+14$ & 145132.1 & 21646.38 & $1.39 \mathrm{E}+$ \\
\hline Dev. & 2161252 . & 204614.4 & 743990.0 & $5.11 \mathrm{E}+25$ & 734408.6 & 922833.8 & $5.40 \mathrm{E}+1$ \\
\hline Observations & $\begin{array}{l}1609 \\
169\end{array}$ & 1609 & 1609 & 1609 & 1609 & 1609 & 1609 \\
\hline
\end{tabular}


The descriptive statistics of the variables in the study are presented in table 3. The descriptive statistics discusses the characteristics of the variables in the study. The table shows that the average stock price in the market within the period of study is 7.412. This implies that the average price of financial stock in the market within the period of the study is 7.42 naira. The maximum price of the stock within the period of the study is 552 while the minimum value is 0.50 . The result shows a standard deviation value of 36 for share price. The high value of standard deviation is due to the high fluctuations in the stock prices witnessed within the period of the study. The data is skewed and kurtotic as depicts by the high value of Skewness and Kurtosis. The value of J arque-Bera statistic is very high and the corresponding value of the probability of Jarque-Bera is 0.0000 which suggests non normality in the data distribution of share price. This is expected as it is common in previous studies in this area. The data are thus normalised using log transformation.
The average value of earnings per share is 1.44, this implies that the financial sector on average earned 1.44 per share. The minimum value recorded is 0.004 while the maximum value of 221.51 the deviation from the mean is 11.28. Considering the average mean, the deviation from the mean is very high. The variable is much skewed and Kurtotic. The variable is not normally distributed due to large variation in firm size. The value of average exchange rate is 143 naira for the period of the study. The minimum value is 103 naira while the maximum value is 180.15 the average volatility in exchange rate is 21 which implies the variable is Skewed and K urtotic. The variable is not normally distributed. The result also shows a market capitalisation has an average of 1 trillion the maximum is 8 trillion. The variable is skewed and kurtotic implying non-normality in data distribution. Also, the average oil price within the period of study is 90.2 dollar per barrel while the highest within the study period is 117.79 dollar per barrel. Like all the other previous variables, oil price is non-normally distributed and it is normalised using log transformation.

Table 2 Correlations Matrix

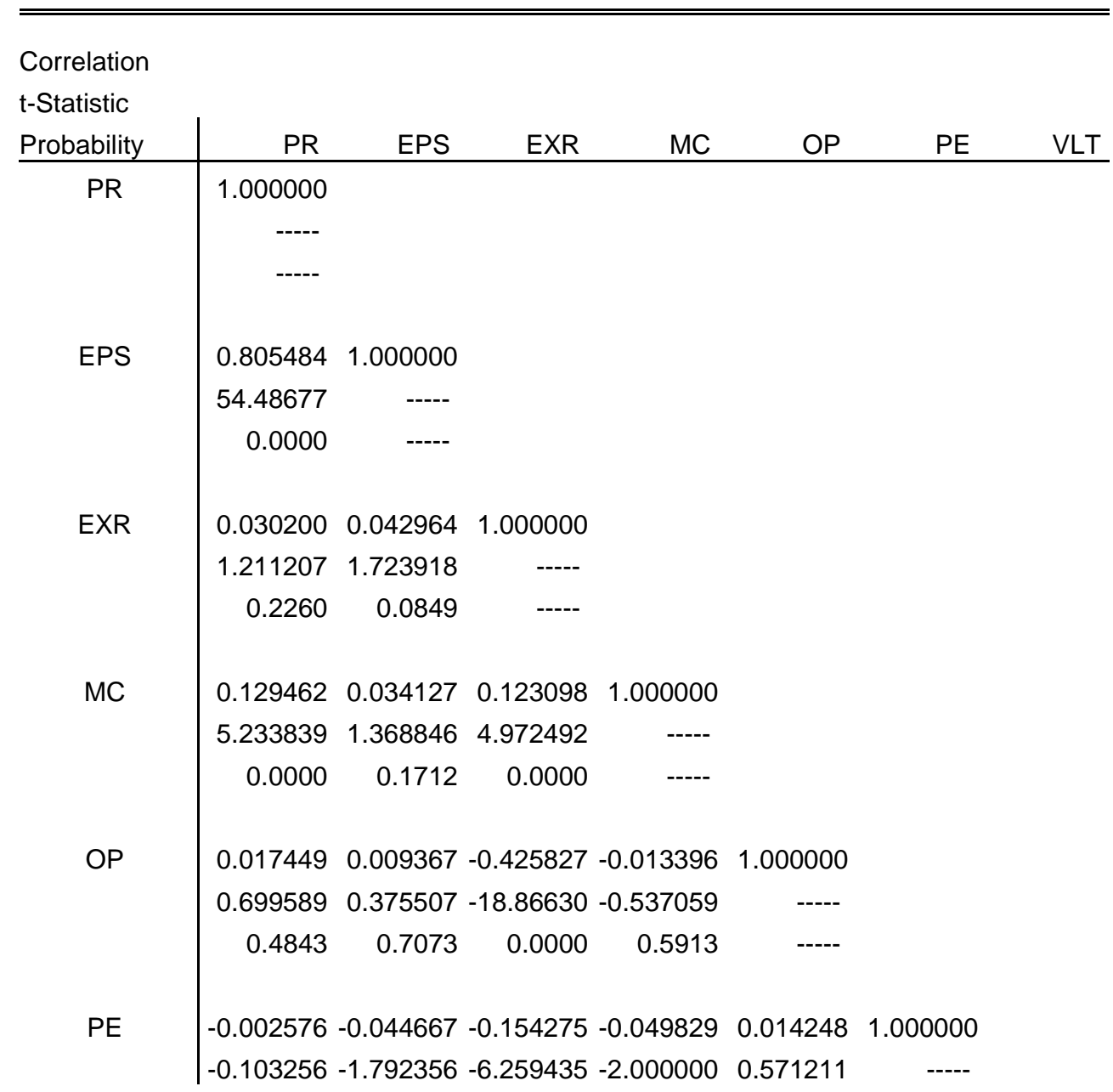




\begin{tabular}{l|rrrrrrr} 
& 0.9178 & 0.0733 & 0.0000 & 0.0457 & 0.5679 & $\cdots--$ & \\
VLT & & & & & & & \\
& 0.014500 & -0.003526 & 0.079334 & 0.324717 & -0.017393 & -0.024485 & 1.000000 \\
0.581329 & -0.141344 & 3.190367 & 13.76287 & -0.697358 & -0.981851 & $-\cdots-$ \\
& 0.5611 & 0.8876 & 0.0014 & 0.0000 & 0.4857 & 0.3263 & $-\cdots--$ \\
\hline \hline
\end{tabular}

\section{Source: Computed using E views}

The result in table 4.2shows the correlation matrix of the variables in the study. The list in the table are the correlation, t-statistic and the probability of the variables. The result shows that the relationship between EPS and PR is $80 \%$ with statistical significance. The relationship between exchange rate and share price is only $3 \%$ without statistical significance. Also oil price and share price have a relationship of $1 \%$ without significance. On the other hand PE and PR have a relationship that is less than $1 \%$ and negative. Also, VLT and PR have a relationship of $1 \%$.

The relationship between the explanatory variables is very weak as showed by the various correlation values. In fact, some of the relationship amongst the independent variables are weak. The result implies that there is no likelihood of multicollinearity. This is confirmed by the variance inflation factor as presented in table 3

Table 3 Variance Inflation Factors

\begin{tabular}{cccc}
\hline \hline Variable & $\begin{array}{c}\text { Coefficient } \\
\text { Variance }\end{array}$ & $\begin{array}{c}\text { Uncentered } \\
\text { VIF }\end{array}$ & $\begin{array}{c}\text { Centered } \\
\text { VIF }\end{array}$ \\
\hline C & 0.252141 & 1.482155 & NA \\
EPS & $1.35 \mathrm{E}-05$ & 1.008025 & 1.006882 \\
EXR & $2.21 \mathrm{E}-06$ & 1.696919 & 1.430718 \\
MC & $1.99 \mathrm{E}-25$ & 1.101200 & 1.095635 \\
OP & $1.81 \mathrm{E}-06$ & 1.398674 & 1.314972 \\
PE & $1.29 \mathrm{E}-06$ & 1.047793 & 1.046038 \\
VLT & $2.37 \mathrm{E}-18$ & 1.008509 & 1.007990 \\
\hline \hline
\end{tabular}

\section{Source: Computed using E views}

The result in table 3 shows the collinearity between the explanatory variables. The result shows that there is no close relationship between the variables as both the centred and uncentred values of the variance inflation factors are less than $5 \%$

Table 4 Hausman Test

Correlated Random Effects - Hausman Test

Equation: GAS 1

Test cross-section random effects

\begin{tabular}{llll}
\hline \hline Test Summary & $\begin{array}{l}\text { Chi-Sq. } \\
\text { Statistic }\end{array}$ & Chi-Sq. d.f. & Prob. \\
\hline \hline Period random & 1.948071 & 4 & 0.7453 \\
\hline \hline
\end{tabular}

Cross-section random effects test comparisons:

\begin{tabular}{lllll} 
Variable & Fixed & Random & Var(Diff.) & Prob. \\
\hline \hline EPS & 0.006740 & 0.142202 & -0.135462 & 0.7123 \\
EXR & -0.016623 & -0.016153 & -0.032776 & 0.5679 \\
MC & 0.000000 & 0.000000 & 0.000000 & 0.2587 \\
OP & -0.006240 & -0.004779 & -0.011019 & 0.9455 \\
PE & 0.004866 & 0.007959 & -0.003093 & 0.0000 \\
VLT & 0.000000 & 0.000000 & 0.000000 & 0.0000 \\
& & 5 & &
\end{tabular}




\section{Source: Computed using E views}

The result in table 4 above shows the result of Hausman test for random effects specification. The value of cross-section random is 1.948 with a probability of 0.7453 which is greater than $5 \%$, this implies that random effect is the best test to be used.

Table 5 Random Effect Regression Result

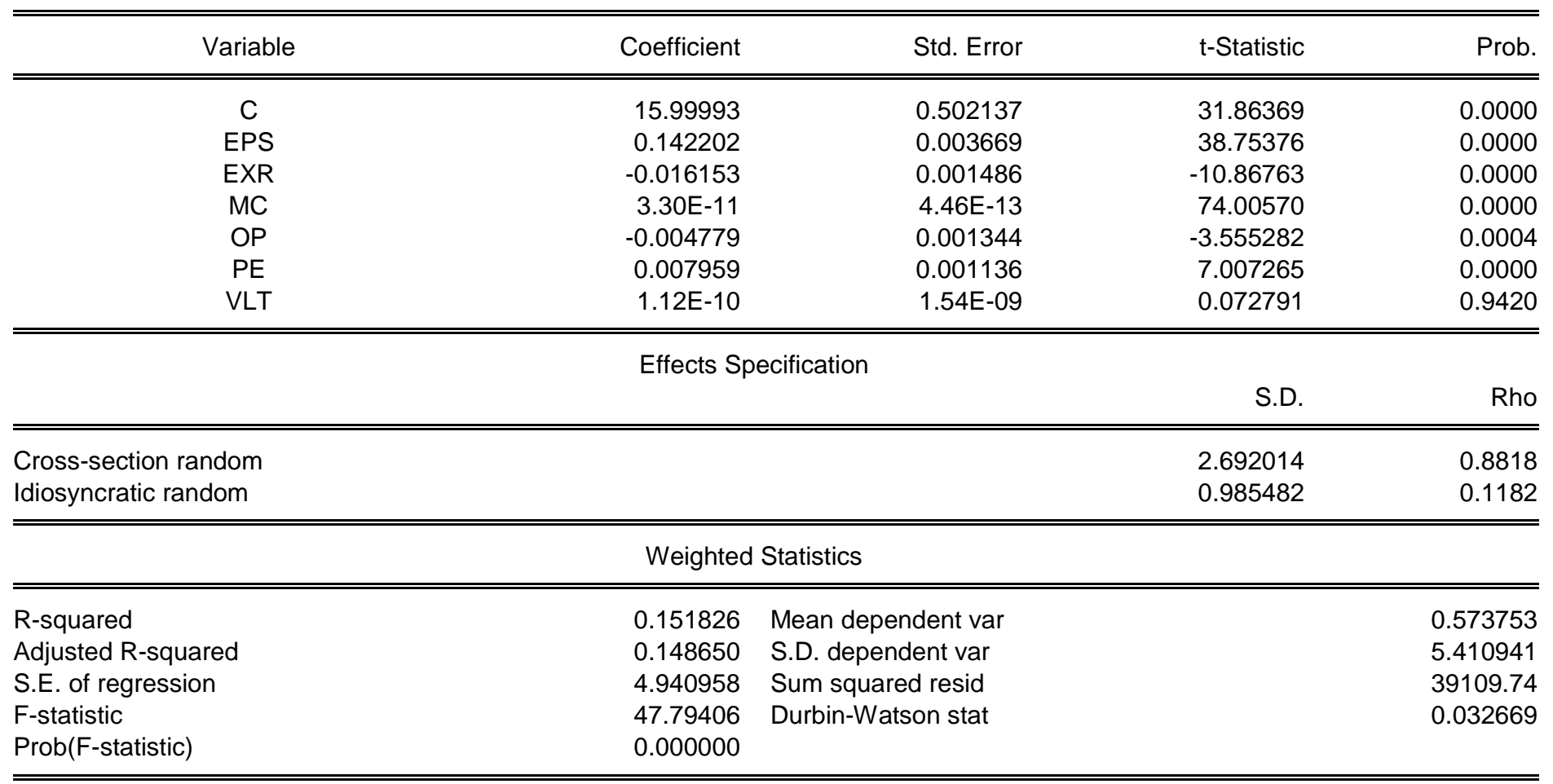

\section{Source: Computed using E views}

The result in table 5 shows the results of the various hypotheses test. The result shows that on aggregate basis, the variables were able to jointly account for only $0.15 \%$ variation in stock prices even inclusion of more explanatory variables would have less impact on the model as the value of adjusted $R$ squared is approximately $15 \%$ too. This result implies that $85 \%$ of the variation stock price is accounted for by other factors not captured in the model. The implication is that the convention accounting variables and the macro economic variables not seriously retain enough memory that will could seriously explain changes in stock prices. On the other hand, this type of result is common in finance literature. The result shows a standard error of 4.94 which is not large thus implying that the low value of $r$-squared is not rely due to serious weakness in the model. The result however depicts case of autocorrelation in the error term but such findings are also common in the finance literature.

The result have shown that the coefficient of the constant in the regression is 15.99 which also shows a probability value of 0.000 . This implies that, in the absence of all the explanatory variables, stock prices increases at a constant rate of 15.99. The explanatory variables jointly could not account up to the constant value in explaining changes in stock price. 
A unit increase in the value of EPS leads to a 0.14 increase in the stock prices of financial sector firms in Nigeria. This result has statistical significance as the value of the probability is 0.0000 which is less than the $5 \%$ test criteria. This implies that the null hypothesis with respect to EPS does not hold.

The result of the test has also indicates that a unit increase in the level of exchange will lead to a 0.016 decrease in the value of share prices. A gain, the result has statistical significance since the pvalue of 0.0000 is less than $5 \%$. The result implies that as the level of exchange rate rises the value of the firms in terms of their stock prices will fall.

A gain, a unit increase in the value of market capitalisation results in a 0.00000003 in the stock price. The result also has statistical significance as the value of the probability is 0.0000 which again means that market capitalisation has significance effect on stock price.

The result also reveals that oil price has a negative effect on the value of stock price. $A$ unit increase in the level of oil price will lead to a 0.004 fall in stock price. The result also has a significant effect as the p-value of 0.0004 is less than the $5 \%$ test critical value.

A unit increase in the value of price earnings ratio will lead to a 0.079 increase in the value of stock price with statistical significance since the $p$-value is 0.0000 . However, a unit increase in the value of volume of transaction which proxy liquidity will lead to a 0.000000012 increase in stock price without statistical significance.

\section{Discussion of Findings}

This study have examined the determinants of share price of listed financial sector firms in Nigeria. The study has found that on aggregate level the variables have significant influence on share prices of listed financial sector firms in Nigeria. However, the magnitude of the influence is not strong as the value of $r$-squared is only $15 \%$. A bedelkarim (2016), Conghni (2013), Chang and Luo (2010) and Teoh, $Y$ ang and Zhang (2009) reported low value of r-squared which they attributed to a greater amount of firm-specific uncertainty or investor overreaction to new firm-specific information. It is also deduced that the low value is indicative of the fact that aside the accounting and macroeconomic variables behavioural factor which could not be captured in this study due to the data nature could as well have explained better since investors sometime influenced by psychological factors rather than market fundamentals.

The study has found that earnings per share is a significant and positive determinant of stock price of financial market with statistical significance. The implication is that as earnings per share of a firm increases investors will patronize more of its share. The increase in the demand of the share will thus force the price of the share to rise. The finding is in line with the fact that accounting fundamentals are the determinants of share price.

The study has also found that exchange rate has a negative link with share price of the firms. A highly volatile exchange rate leaves investor with uncertainty about the market. Investors (especially foreign ones) could sell off their shares in anticipation of favorable rate change to repatriate their funds which then causes low demand of the shares there by reducing their values. The finding contradicts that of Naik and Padhi (2012) who found a positive but insignificant link between exchange rate and stock prices. The differences is likely due to designs of the study. While this study used monthly rates with panel regression, their study rather adopted the time series approach.

Again, the study has found that market capitalization is a positive determinant of stock price with statistical significance. This finding is in line with the assumption that as a firm with high capitalization will attract more customers thus increasing its price. Since capitalization is a function of price and a linear relationship is expected. However, in line with the three factor model of Fama (1992), some investors might patronize more of a less capitalized firm with the anticipation of future rise in the price.

The study has found a significant negative link between share price and oil price. This find has two implications. Investors could move to commodity market as their prices rise or that a investors in the market could move from investment in the financial sector to oil sector thus causing depreciation in the prices of the shares of financial sector firms. Also, a hike in oil prices causes panic in the system therefore, at such periods there is a withdrawer from active investment which then forces a fall in the share price. This finding is supported by the work of Quadir (2012). 
It is also found that PE is a significant determinant of stock price. Like EPS, it is was expected that as the rate of EPS rises, stock price will also rise. This finding is in line with that of Srinivasa, Kumar and Rajat, (2013). On the other hand, the other variable that shows non-significant link is value of trade which is a proxy for liquidity.

\section{CONCLUSION AND RECOMMENDATIONS}

This study has examined the determinants of stock price of financial sector firms listed in the Nigerian stock exchange. The determinants studied in this work are: earnings per share, exchange rate, oil price, market capitalization, price earnings ratio and value of transaction in the market. The study, by using monthly data for all the variables was able to establish that all the variables except value of transaction are significant determinants of stock price. However, the magnitude with which the variables were able to explain the link is only $15 \%$, though such low rate is common in literature.

The study has also found that oil price and exchange rate which are the proxies for macroeconomic variable in this work all have negative and significant influence on stock price. The explanation for this is that first, as exchange rate rises and in favor of foreign investors they will repatriate their capital thereby reducing demands form the stocks which then leads to a drop in share prices. High and unfavorable exchange rate increases the cost of doing business which then hinders the firms from meeting their targets and consequently force investors to reduce patronage of their stock. On oil price, it concluded that it leads to drop in share price due to the important role it play in every economic activity. As the prices of oil rises some investors will move away from financial stocks to oil stock which then reduces the prices of financial firm stock.. It is recommended that since the macroeconomic variables shows negative effects on share prices, government must pursue a stable macroeconomic policy that will help stabilize the exchange rate. This will keep the performance of the market stable and encourage more stability of prices in the market.

All the accounting fundamental variables have positive influence on stock prices. This is in line with the argument of the weak-form efficiency of stock price movement. The study concludes that these variables are key determinants of stock price movement of the financial sector firms in Nigeria. It is also recommended that firms can increase the prices of their shares by enhancing their capitalization. This could be achieved through a stable performance as reflected in their earning and could as well issue more shares.

\section{REFERENCES}

1) A bedelkarim, S.F. (2016). Business cycles and stock market returns predictability evidence from continental Europe. Published PhD thesis, Faculdadedeeconomiauniversidede de Porto

2) A rouri, M.E.H., \&Rault., C. (2010). Oil Prices and Stock Markets: What Drives what in the Gulf Corporation Council Countries? CESifo working paper series, No. 2934.

3) Chang, E.C., \& Luo, R (2010). R-Square, noise, and stock returns. Working paper, University of Hong Kong.

4) Chukwunonso, T.O (2014). Effect of oil price movement on stock prices in the Nigerian Equity $M$ arket. Research Journal of Finance and A ccounting. Vol.5, N o.15,

5) Conghni (2013). Implication of low r-squared: evidence from China. Journal of emerging finance and trade, $\mathrm{V}$ ol. 49 , No

6) Eita, J.H. \&Jordaan, A.C. (2010). A causality analysis between financial development and economic growth for Botswana. African Finance Journal, 12(1): 7289.

7) Frank, O., Evans, K.G \& Newman, A (2016). The effect of earnings announcement on share price of manufacturing companies on the Ghana stock exchange. European J ournal of A ccounting, A uditing and Finance Research $\mathrm{V}$ ol.4, N o.6,

8) Henriques, I. \& Sadorsky, P. (2008). Oil prices and the stock prices of alternative energy companies. Energy Economics, 30 Issue 3.

9) Kamunde L.K (2012). Analysis of the relation between market capitalization and stock market indices at the NSE. A research project presented in partial fulfillment of the requirement for the award of the degree of master of business administration, school of business, university of $\mathrm{N}$ airobi

10) Khan, K. I, A amir, M., Qayyum, A, Nasir, A., \& K han, M . I. (2011). Can dividend decisions affect the stock prices: A case of dividend paying companies of KSE.International Research Journal of Finance and E conomics, 76, 67-74.

11) Matthew, O.M Innocent, E.C \& A nyanwaokoro, M (2014). Effect of dividend payment on the market price of shares: A Study of Quoted Firms in Nigeria. IOSR J ournal of Economics and Finance, Volume 5, Issue 4.

12) M butor, 0 . (2007). The lending channel of monetary policy transmission in Nigeria; Vector A utoregressive (V A R) V erification, Central $B$ ank of Nigeria; Economic and Financial Review $\mathrm{V}$ ol 45

13) Oluwatoyin, $M \&$ \& G badebo, 0.0 (2009). The impact of share market capitalization on a company's performance: A case study in the Nigerian confectionary industry 
14) Quadir, M.M (2012). The effect of macroeconomic variables on stock returns on Dhaka stock exchange. International journal of economics and financial issues. $\mathrm{V}$ ol. 2. No4

15) Rahman, A. A bdul, N oor, Z. M ohdSidek\& Fauziah H. T. (2009). Macroeconomic Determinants of $M$ alaysian Stock $M$ arket. A frican J ournal of B usiness $M$ anagement, 3 (3): 95- 106.

16) Srinivasan, P. (2012). Determinants of equity share prices in India: A Panel Data Approach. The Romanian Economic J ournal

17) Teoh, S., Y ang, $Y \&$ \&hang, $Y$ (2009). R-square and market efficiency. Working paper, Department of Accounting, University of California, L os A ngeles.

18) Udegbunam, Ralph I. \& Eriki, P. O. (2001). Inflation and stock price behavior: evidence from Nigerian Stock $M$ arket. J ournal of Financial $M$ anagement and A nalysis, XX (14) (1): 1-10.

19) Y akubu, A.S., Elijah, A \& Sampson, V.E (2013). Effects of earnings announcement on share price: the case of $\mathrm{G}$ hana stock exchange. International J ournal of Research In Social Sciences Vol. 2, No.4 